UNDERGRADUATE RESEARCH IN NATURAL AND CLINICAL SCIENCE AND TECHNOLOGY (URNCST) JOURNAL Read more URNCST Journal articles and submit your own today at: https://www.urncst.com

\title{
Disrupting Biofilm Formation and Antibiotic Resistance in Pseudomonas aeruginosa Using Phage-Delivered Sensitivity Cassettes: A Research Protocol
}

\author{
Isabell C. Pitigoi, BScH Student [1]*, Courtney E. Ostromecki, BScH Student [1], \\ Madelyn A. Fischer, BSc Student [2], Mitchell Shorgan, BSc Student [3]
}

[1] Department of Biomedical and Molecular Sciences, Queen's University, Kingston, Ontario, Canada K7L 3N6

[2] Department of Biomedical Sciences, University of Guelph, Guelph, Ontario, Canada N1G 2W1

[3] Department of Integrative Biology, University of Guelph, Guelph, Ontario, Canada N1G 2W1



*Corresponding Author: isabell.pitigoi@queensu.ca

\begin{abstract}
Introduction: Despite antimicrobial resistance topping the list of global health concerns, the development of novel antibiotics has been nearly abandoned due to strict regulations and dwindling economic incentives in the pharmaceutical industry. There is a critical need for alternative strategies to treat multidrug resistant pathogens like Pseudomonas aeruginosa $(P$. aeruginosa), a pestilent cause of nosocomial infections. Here, we aim to target adaptive resistance in $P$. aeruginosa biofilms by inducing hypersensitivity to existing antibiotics through phage-delivery of a particular gene cassette. Previous studies have suggested that the rpoS gene is repressed in $P$. aeruginosa biofilms and that its deletion is correlated with hypervirulence, increased biofilm thickness and antibiotic resistance.

Methods: In this protocol, we aim to explore the effect of inducing rpoS overexpression in $P$. aeruginosa colonies as a potential method to disrupt biofilm structure and increase sensitivity to tobramycin. Phagemids containing rpoS, an accompanying promoter, and a tellurite resistance gene are delivered by P1 bacteriophages to the biofilm to be shared through horizontal gene transfer (HGT). Tellurite is then administered to induce selective pressure for HGT, by favouring uptake of the phagemids due to the presence of the tellurite resistance gene. Consequently, we can assess the effect of rpoS overexpression on biofilm organization and tobramycin sensitivity using measures from confocal laser scanning microscopy (CLSM).

Anticipated Results: Given the hypervirulent effects of rpoS deletion, we expect that forcing rpoS overexpression in $P$. aeruginosa would result in decreased biofilm thickness compared to controls. Furthermore, the colonies are also expected to have lower cell viability following tobramycin administration.

Discussion: Overall, our experiment characterizes the effects of rpoS overexpression on biofilm thickness, cell viability and tobramycin resistance. As such, this protocol may have practical implications for re-sensitization of P.aeroginosa to antibiotics.

Conclusion: This would demonstrate a potential for phage-mediated hypersensitization of $P$. aeruginosa that is adaptable to more practical settings, such as in situ on hospital surfaces.
\end{abstract}

Keywords: Pseudomonas aeruginosa; antibiotic sensitivity; tobramycin resistance; biofilm; phage-delivery; flow cell confocal microscopy

\section{Introduction}

Multi drug-resistant pathogens are responsible for an estimated 700,000 deaths annually, a number which is expected to reach 10 million by 2050 [1]. Among them is $P$. aeruginosa, an opportunistic pathogen known for causing nearly 14 percent of all nosocomial infections and even more in intensive care units [2]. Along with intrinsic and acquired resistance, this bacterium displays adaptive resistance in biofilms by modifying gene expression in response to environmental stressors such as antibiotics $[3,4]$ In a biofilm, bacteria can withstand aggressive antibiotic therapy and are more resilient in producing severe infections in chronic wounds, implanted biomaterials, and urinary catheters [5-7]. While tobramycin is currently used as a front-line antibiotic in $P$. aeruginosa therapy, these biofilms have been shown to resist tobramycin levels that are 100 times greater than those administered therapeutically [8]. Developing a mechanism to disrupt biofilm formation would therefore undermine adaptive resistance by improving antibiotic permeability and impairing intracellular communications. Bacteriophages are prime candidates for penetrating biofilms because they are 
naturally optimized to infect these types of colonies without conferring toxicity to humans due to high host specificity $[9,10]$. Previous work has pre-emptively explored the use of bacteriophages in restoring antibiotic sensitivity, although not specifically through the disruption of biofilm [11,12].

It has been shown that the rpoS gene is silenced during biofilm formation and that its deletion yields resistance to tobramycin in P. aeruginosa [13]. This prompted us to test whether overexpression of rpoS would instead act as a sensitizing element to disrupt biofilms and thus render them more sensitive to tobramycin. Phagemids are useful vectors that are transported as linear DNA within bacteriophage capsids and recircularized within host bacterial cells. Here, we use the P1pBHR-bla phagemid to deliver rpoS along with a strong promoter for overexpression, as it is known to be compatible with the P1 bacteriophage in both $P$. aeruginosa and Escherichia coli [14]. It also already contains an ampicillin-resistance gene for selection and a pac sequence that signals for it to be packaged into the P1 phage. Phagemids are self-replicating units and spread efficiently throughout a population by promoting interbacterial interactions, particularly in biofilms, which promote stability and foster higher HGT traits [15]. In this protocol, we aim to further motivate phagemid uptake through HGT by use of tellurite; an oxidized derivative of the trace element tellurium which has been used experimentally to exert toxicity on $P$. aeruginosa [16]. It mainly does so through generation of superoxide radicals that cause bacterial oxidative burst, but has also been found to interfere with protein synthesis. Studies have isolated the thiopurine-S-methyltranferase (tpm) gene, which, along with the strong $\mathrm{pX} 2$ promoter, is able to reduce or convert tellurite into metallic or volatile forms, therefore conferring resistance [17]. Therefore, by including tpm in the phagemid and administering tellurite after phage-delivery to the biofilm, we should elicit a selective pressure which favours phagemid uptake. The goal is to thereby determine whether the resultant rpoS overexpression would be effective in stimulating the conversion of biofilms to a planktonic state. Additionally, we are interested in whether this change in colony structure would serve as a method of restoring tobramycin sensitivity in $P$. aeruginosa.

\section{Methods}

Phagemid Construction

rpoS is amplified by PCR using primers that contain cut sites for different restriction enzymes. The PCR products are digested with these enzymes and ligated directionally into the P1pBHR-bla phagemid in place of non-essential phage genes. Similarly, a strong promoter allowing for overexpression of rpoS, the tellurite resistance gene and an enhanced green fluorescent protein (eGFP) gene for microscopy are inserted in-line on the same vector.

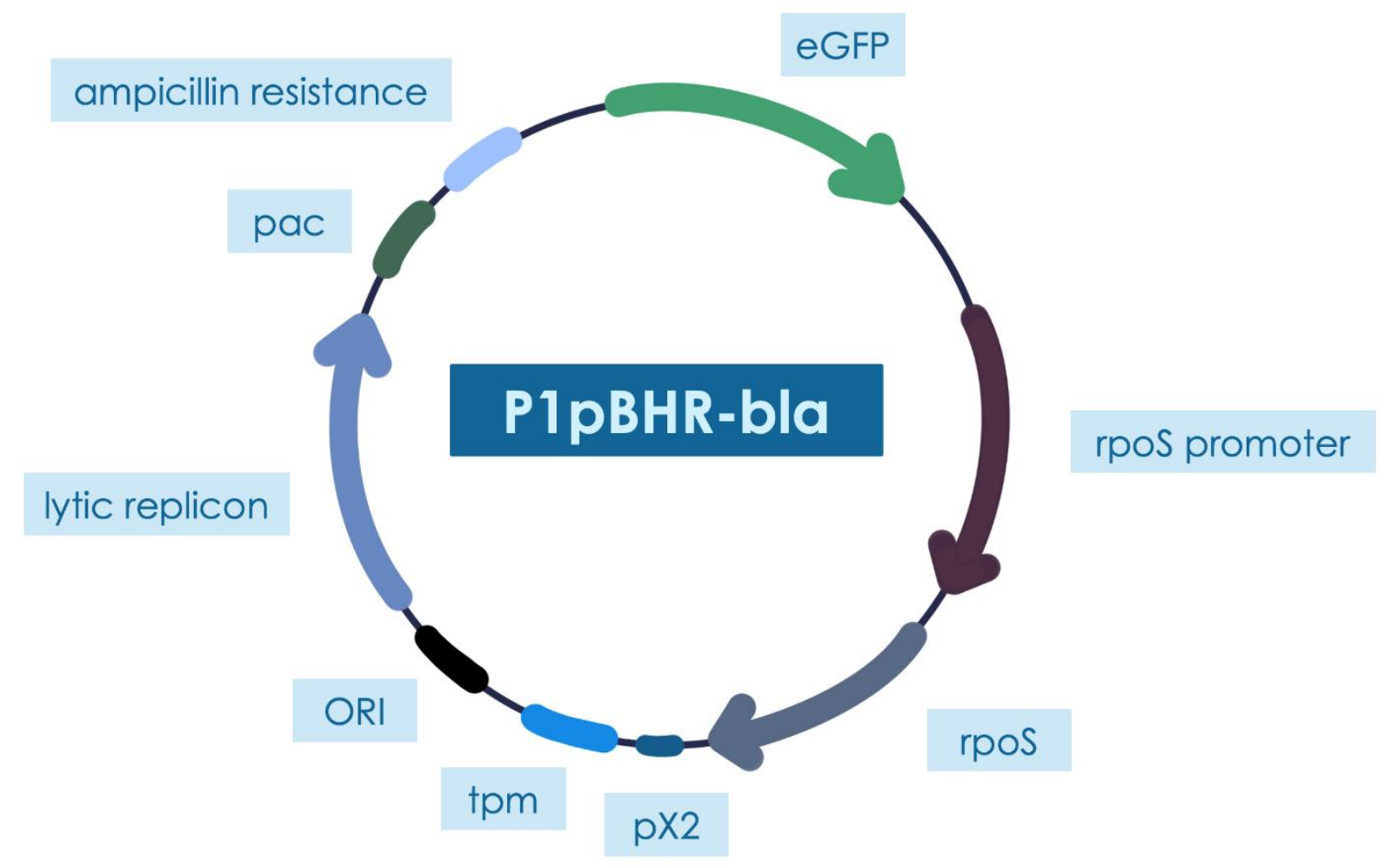

Figure 1. Phagemid element organization (illustrated using Microsoft OneNote). 
UNDERGRADUATE RESEARCH IN NATURAL AND CLINICAL SCIENCE AND TECHNOLOGY (URNCST) JOURNAL Read more URNCST Journal articles and submit your own today at: $\underline{\text { https://www.urncst.com }}$

Phage Preparation in E. coli

The resulting phagemid is transformed into E. coli, selected for by ampicillin, and packaged into P1 bacteriophages. A control phagemid is produced in the same manner, except that it does not contain the rpoS gene or its respective promoter. Engineered P1 bacteriophages are verified by PCR for the presence of the expected DNA fragments and then replicated as needed for transduction.

\section{Preparation of Monospecies $P$. aeruginosa Biofilm}

Fifteen fresh overnight cultures of $P$. aeruginosa strain PA14 are prepared with a starting $\mathrm{OD}_{600}$ of 0.1 and loaded into syringes [18]. The Sterile Treatment Imaging Flow Cells are inoculated using the syringe containing the PA14 suspension. PA14 biofilms are then cultivated in appropriate growth medium (fastidious anaerobe broth (FAB) medium with $0.3 \mathrm{mM}$ citrate) at $37^{\circ} \mathrm{C}[18,19]$. Following a settling period of 30 minutes, the bacterial cells establish a biofilm on the glass coverslip substratum and a constant flow rate is initiated $(\sim 3.3 \mathrm{ml} \mathrm{h}-1$ per channel) using a peristaltic pump positioned upstream of the flow cell. Prior to any manipulations, all flow cells are incubated for 48 hours and mounted on a stage for fluorescent CLSM so that images can be captured at 25-minute intervals beginning at flow start.

\section{Biofilm Transduction}

To establish an untreated control, three flow cells (\#1, 2,3 ) are not exposed to any treatment to assess the natural behaviour and structure of P.aeruginosa biofilms. Flow cells \#4 through 9 are transduced with the engineered P1 bacteriophages harboring the control phagemid (which contains all elements except the rpoS gene and its associated promoter). Then, flow cells \#10 through 15 are transduced with P1 bacteriophages containing the rpoS phagemid (from Figure 1). Tellurite is administered to flow cells \#7, 8, 9, 13, 14 and 15 to enrich for bacteria harbouring the resistance-conferring cassette. For comparison, flow cells \#4, 5, 6, 10, 11, and 12 do not receive tellurite treatment to confirm that tellurite is indeed inducing selective pressure for the bacteria to take up the resistance-conferring cassette. The control and treatment groups are shown in Figure 2 below.

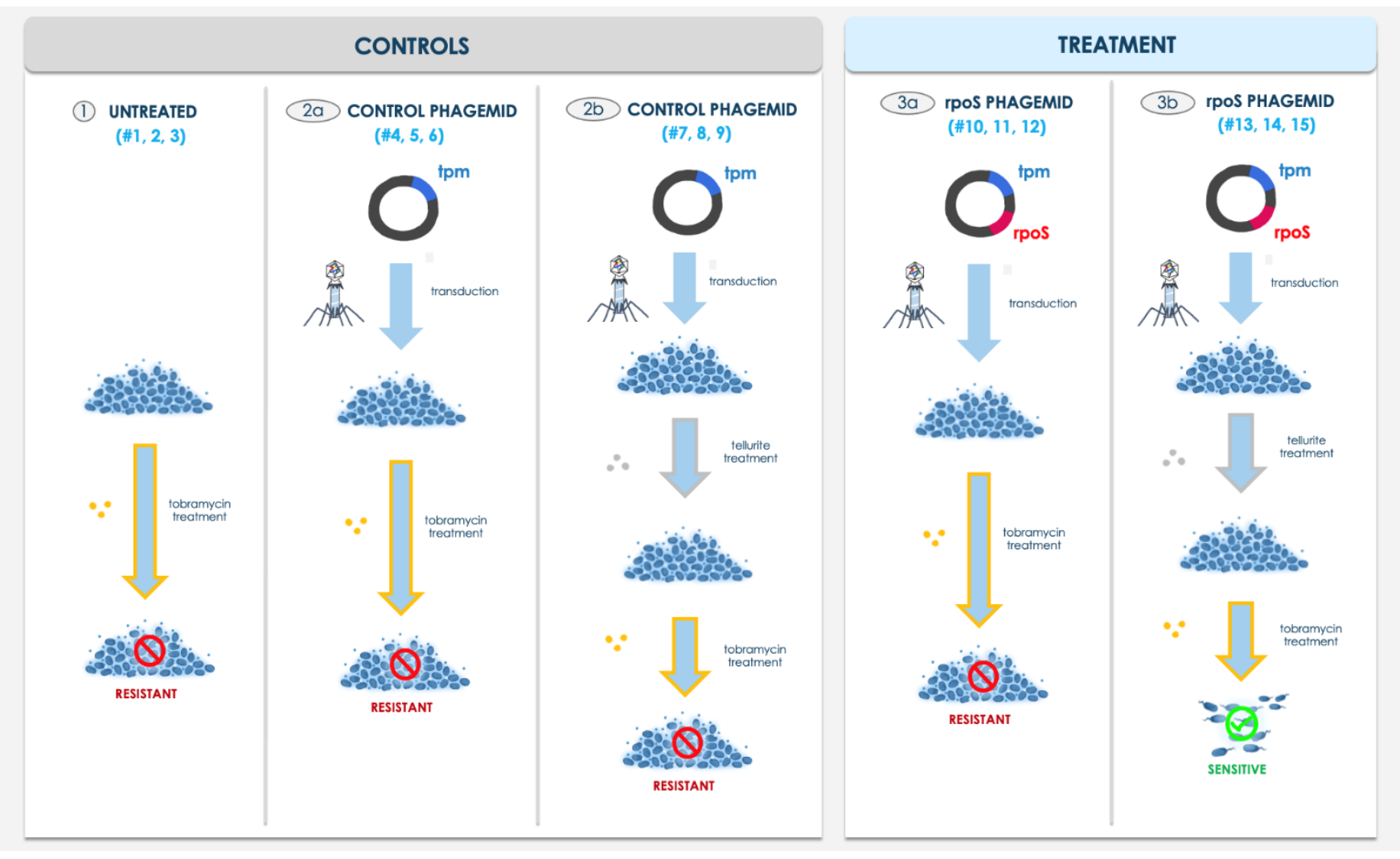

Figure 2. General overview of flow cell methodology (illustrated using Microsoft OneNote).

\section{Antibiotic Sensitivity Testing}

For each group of three flow cells receiving the same treatment, each one is subject to a different length of antibiotic exposure: $1 \mathrm{hr}, 4 \mathrm{hr}$, and continuous. The antibiotic, tobramycin, is administered at a standard therapeutic concentration of $10 \mu \mathrm{g} \mathrm{ml}-1$, corresponding to 10 times the minimal inhibitory concentration (MIC) of this antibiotic (MIC: $1 \mu \mathrm{g} \mathrm{ml}-1$ ) [19]. This is done by pausing 
UNDERGRADUATE RESEARCH IN NATURAL AND CLINICAL SCIENCE AND TECHNOLOGY (URNCST) JOURNAL Read more URNCST Journal articles and submit your own today at: https://www.urncst.com

the pump, preventing reflow with clamps, and emptying then refilling the tubes and bubble traps upstream of the clamps with FAB medium containing the antibiotic. Clamps are then removed, and flow is resumed.

\section{$\underline{\text { Image Acquisition and Analysis }}$}

Biofilm formation is monitored by CLSM using an inverted Leica TCS SP2 system with argon/krypton lasers and detectors [20]. Live cell staining makes use of eGFP (excitation, $488 \mathrm{~nm}$; emission, $509 \mathrm{~nm}$ ) and dead cell staining utilizes propidium iodide (excitation, $543 \mathrm{~nm}$; emission, $565 \mathrm{~nm}$ ), allowing for comparisons of cell viability. Biofilm images taken at 25-minute intervals are analyzed in stacks using COMSTAT. Quantitative measurements of mean thickness and thickness distribution, biomass, roughness, substratum coverage and surface to volume ratio are obtained and assessed for statistically significant differences between treatments [21].

\section{Results}

We would expect the $P$. aeruginosa culture overexpressing rpoS (Treatment $3 \mathrm{~b}$ in Figure 2) to demonstrate reduced biofilm formation, compared to the other treatment groups and controls. This would be observed quantitatively as a decrease in mean thickness and substratum coverage. We would also expect this culture to have a lower cell viability compared to controls when exposed to the same concentration and length of treatment with the tobramycin antibiotic.

\section{Discussion}

Here, we present a novel approach to combat multi drug-resistant pathogens residing on hospital surfaces. The expected decrease in both biofilm thickness and antibioticsurviving cells would establish this method as a promising therapy for reversing resistance. These results would also indicate that rpoS overexpression produces an opposite effect to underexpression, which would be a valuable discovery in $P$. aeruginosa research. Our protocol would thereby serve as a proof of concept for restoring tobramycin sensitivity in this bacterial species by delivery of sensitizing genetic material to biofilms in exchange for tellurite resistance. Unlike conventional phage therapy, this approach does not use phages to directly kill pathogens, and rather uses them as delivery vehicles for the phagemid of interest. This method is therefore superior as it does not promote selection against the phages because the transduction step is not itself hostile to the bacterium, and the plasmid instead confers an initial reproductive advantage when cells are exposed to tellurite. Furthermore, rather than being administered to patients, we intend for these phages to be utilized solely for dispersal on hospital surfaces. By avoiding the use of phages in a clinical context, our approach overcomes toxicity issues associated with internal use of tellurite and evades other potential drawbacks including phage neutralization by the host.
CLSM is the preferred microscopy technique for biofilms because it captures high-resolution images at various depths which can then be compiled into a 3D reconstruction for quantification and analysis by COMSTAT software [22]. The program's image processing and analysis algorithms provide an efficient way to output quantitative data from these images, by calculating several parameters related to biofilm structure and function. Thus, the different samples can be easily compared without having to rely on qualitative observations of volume, surface area coverage, thickness, distribution, and roughness, among other characteristics. Our experimental setup is also particularly beneficial as it allows for the biofilm to be quantified directly in the vessel in which it is being treated, allowing us to avoid any additional manipulations that could interfere with the integrity of the structure.

Future experiments can be further modified to diminish the possibility of the tellurite resistance gene being horizontally transferred without overexpression of the rpoS sensitizing gene. For instance, the rpoS cassette can be strategically placed preceding a promoterless tellurite resistant gene within the phagemid so that acquiring tellurite resistance would be conditional upon overexpression of rpoS. In future experiments, the phagemid could also be equipped with a diverse array of antibiotic-sensitizing genes rather than just rpoS in order to reduce the possibility of spontaneously regaining resistance against all these antibiotics at once.

\section{Conclusions}

This protocol presents a novel method for targeting $P$. aeruginosa biofilms via phage-mediated delivery of sensitizing genetic material. Previous studies have established precedent for phage-delivery of sensitizing genes in other bacteria but restoring sensitivity by genetic manipulation of biofilms has not been previously explored with this pathogen. Therefore, the purpose of this experiment is to promote understanding of specific $P$. aeruginosa genes, their correlation with biofilm formation, and resistance to existing antibiotics. Additionally, we are testing the protocol of phage-mediated delivery of sensitizing genetic material, particularly in terms of the efficacy of the tellurite selection mechanism. Although the toxic nature of tellurite poses limitations to clinical applications, this experiment may allow for significant advancements in other areas of the field. Given the anticipated effects of rpoS overexpression, we hope to inspire techniques for targeting resistant $P$. aeruginosa biofilms on hospital surfaces, which is particularly relevant for preventing drug resistant $P$. aeruginosa from establishing chronic nosocomial infections. This experiment also elicits further questions regarding the methods used. Perhaps this experiment may be adapted to establish sensitivity in and target other relevant $P$. aeruginosa genes as well as other bacterial species. 
UNDERGRADUATE RESEARCH IN NATURAL AND CLINICAL SCIENCE AND TECHNOLOGY (URNCST) JOURNAL Read more URNCST Journal articles and submit your own today at: https://www.urncst.com

Additionally, further research to discover alternative selection mechanisms that do not involve toxins can provide many beneficial clinical applications. Regardless of the outcome, the results of this study would inform future experiments on the role of rpoS in biofilm formation and tobramycin resistance, as well as clarify the effect of rpoS overexpression. Given these directions, we are hopeful that this experiment would act as a major step in combatting antimicrobial resistance in $P$. aeruginosa and beyond.

\section{List of Abbreviations Used}

CLSM: confocal laser scanning microscopy

eGFP: enhanced green fluorescent protein

FAB: fastidious anaerobe broth

HGT: horizonal gene transfer

MIC: minimal inhibitory concentration

\section{Conflicts of Interest}

The author(s) declare that they have no conflict of interests.

\section{Ethics Approval and/or Participant Consent}

This research protocol did not require ethics approval and/or participant consent.

\section{Authors' Contributions}

IP: Contributed substantially to the conception and design of the study, drafted and revised the manuscript critically, and gave final approval of the version to be published.

CO: Contributed substantially to the conception and design of the study, drafted and revised the manuscript critically, and gave final approval of the version to be published.

MF: Contributed substantially to the conception and design of the study, drafted and revised the manuscript critically, and gave final approval of the version to be published.

MS: Contributed substantially to the conception and design of the study, drafted and revised the manuscript critically, and gave final approval of the version to be published.

\section{Acknowledgements}

None.

\section{Funding}

This study was not funded.

\section{References}

[1] World Health Organization International [Internet]. New report calls for urgent action to avert antimicrobial resistance crisis. [cited 2019 Apr 29]. Available from: https://www.who.int/news/item/29-042019-new-report-calls-for-urgent-action-to-avertantimicrobial-resistance-crisis

Pitigoi et al. | URNCST Journal (2021): Volume 5, Issue 12

DOI Link: https://doi.org/10.26685/urncst.315
[2] Driscoll JA, Brody SL, Kollef MH. The epidemiology, pathogenesis and treatment of Pseudomonas aeruginosa infections. Drugs [Internet]. 2007;67(3): 351-68. http://doi.org/10.2165/00003495-200767030$\underline{00003}$

[3] Fernández L, Breidenstein, EBM, Hancock, REW. Creeping baselines and adaptive resistance to antibiotics. Drug Resistance Updates. 1998 Mar 1;14(1):1-21. http://doi.org/10.1016/j.drup.2011.01.001

[4] Rasamiravaka T, Labtani Q, Duez P, El Jaziri M, Chorianopoulos N. The formation of biofilms by Pseudomonas aeruginosa: A review of the natural and synthetic compounds interfering with control mechanisms. Biomed Research International. 2015 Mar 19;2015:1-17. https://doi.org/10.1155/2015 /759348

[5] Mulcahy LR, Isabella VM, Lewis K. Pseudomonas aeruginosa biofilms in disease. Microbial Ecology. 2013 Oct 6;68(1):1-12. http://doi.org/10.1007/s00248013-0297-X

[6] Costerton W, Veeh R, Shirtliff M, Pasmore M, Post C, Ehrlich G. The application of biofilm science to the study and control of chronic bacterial infections. Journal of Clinical Investigation. 2003 Nov 15;112(10):1466-77. http://doi.org/10.1172/JCI20032 $\underline{0365}$

[7] Stoodley P, Hall-Stoodley L, Costerton B, DeMeo P, Shirtliff M, Gawalt E, et al. Biofilms, biomaterials, and device-related infections. Handbook of Polymer Applications in Medicine and Medical Devices. 2013;77-101. http://doi.org/10.1016/B978-0-323$\underline{\text { 22805-3.00005-0 }}$

[8] Nickel JC, Ruseska I, Wright JB, Costerton JW. Tobramycin resistance of Pseudomonas aeruginosa cells growing as a biofilm on urinary catheter material. Antimicrobial Agents and Chemotherapy. $1985 \mathrm{Apr}$ 1;27(4):619-24. http://doi.org/10.1128/AAC.27.4.619

[9] Pires DP, Sillankorva S, Azeredo J. The use of bacteriophages for $P$. aeruginosa biofilm control. 1st Portuguese Biomedical Engineering Meeting. 2011. http://doi.org/10.1109/ENBENG.2011.6026045

[10] Chegini, Z., Khoshbayan, A., Taati Moghadam, M., Farahani, I., Jazireian, P., \& Shariati, A. Bacteriophage therapy against Pseudomonas aeruginosa biofilms: A review. In Annals of Clinical Microbiology and Antimicrobials. 2020;19(1). https://doi.org/10.1186/ s12941-020-00389-5

[11] Edgar R, Friedman N, Molshanski-Mor S, Qimron U. Reversing bacterial resistance to antibiotics by phagemediated delivery of dominant sensitive genes. Applied and Environmental Microbiology. 2011 Nov 23;78(3):744-51. http://doi.org/10.1128/AEM.05741-11 
UNDERGRADUATE RESEARCH IN NATURAL AND CLINICAL SCIENCE AND TECHNOLOGY (URNCST) JOURNAL Read more URNCST Journal articles and submit your own today at: https://www.urncst.com

[12] Chan BK, Sistrom M, Wertz JE, Kortright KE, Narayan D, Turner PE. Phage selection restores antibiotic sensitivity in MDR Pseudomonas aeruginosa. Scientific Reports. 2016 May 26;6(1). http://doi.org/10.1038/srep26717

[13] Whiteley M, Bangera MG, Bumgarner RE, Parsek MR, Teitzel GM, Lory S, et al. Gene expression in Pseudomonas aeruginosa biofilms. Nature. 2001 Oct;413(6858):860-4. http://doi.org/10.1038/35101627

[14] Westwater C, Schofield DA, Schmidt MG, Norris JS, Dolan JW. Development of a P1 phagemid system for the delivery of DNA into gram-negative bacteria. Microbiology. 2002 Apr 1;148(4):943-50. http://doi.org/10.1099/00221287-148-4-943

[15] Madsen JS, Burmølle M, Hansen LH, Sørensen SJ. The interconnection between biofilm formation and horizontal gene transfer. FEMS Immunology and Medical Microbiology. 2012 Jul;65(2):183-95. http://doi.org/10.1111/j.1574-695X.2012.00960.X

[16] Prigent-Combaret C, Sanguin H, Champier L, Bertrand C, Monnez C, Colinon C, et al. The bacterial thiopurine methyltransferase tellurite resistance process is highly dependent upon aggregation properties and oxidative stress response. Environmental Microbiology. 2012 Jun 19;14(10):2645-60. http://doi.org/10.1111/j.1462-2920.2012.02802.x

[17] Cunrath O, Meinel DM, Maturana P, Fanous J, Buyck JM, Saint Auguste P, et al. Quantitative contribution of efflux to multi-drug resistance of clinical Escherichia coli and Pseudomonas aeruginosa strains. EBioMedicine. 2019 Mar;41:479-87. http://doi.org/ $\underline{10.1016 / j . e b i o m .2019 .02 .061}$
[18] Crusz SA, Popat R, Rybtke MT, Cámara M, Givskov $\mathrm{M}$, Tolker-Nielsen T, et al. Bursting the bubble on bacterial biofilms: A flow cell methodology. Biofouling. 2012 Aug 9;28(8):835-42. http://doi.org/ 10.1080/08927014.2012.716044

[19] Müsken M, Pawar V, Schwebs T, Bähre H, Felgner S, Weiss S, et al. Breaking the vicious cycle of antibiotic killing and regrowth of biofilm-residing Pseudomonas aeruginosa. Antimicrobial Agents and Chemotherapy. 2018;62. http://doi.org/10.1128/AAC.01635-18

[20] Verotta D, Haagensen J, Spormann AM, Yang K. Mathematical modeling of biofilm structures using COMSTAT data. Computational and Mathematical Methods in Medicine. 2017;1-11. http://doi.org/10 $.1155 / 2017 / 7246286$

[21] Heydorn A, Nielsen AT, Hentzer M, Sternberg C, Givskov M, Ersbøll BK, et al. Quantification of biofilm structures by the novel computer program COMSTAT. Microbiology. 2000 Oct 1;146(10):2395407. http://doi.org/10.1099/00221287-146-10-2395

[22] Wilson C, Lukowicz R, Merchant S, Valquier-Flynn H, Caballero J, Sandoval J, et al. Quantitative and qualitative assessment methods for biofilm growth: A mini-review. 2017 Dec;6(4). https://www.ncbi.nlm.nih $. g o v / p m c / a r t i c l e s / P M C 6133255 /$

\section{Article Information}

Managing Editor: Jeremy Y. Ng

Peer Reviewers: Daniel Tarade, Jala Rizq

Article Dates: Received Aug 10 21; Accepted Oct 21 21; Published Dec 1721

\section{Citation}

Please cite this article as follows:

Pitigoi IC, Ostromecki CE, Fischer MA, Shorgan M. Disrupting biofilm formation and antibiotic resistance in Pseudomonas aeruginosa using phage-delivered sensitivity cassettes: A research protocol. URNCST Journal. 2021 Dec 17: 5(12).

https://urncst.com/index.php/urncst/article/view/315

DOI Link: https://doi.org/10.26685/urncst.315

\section{Copyright}

(C) Isabell C. Pitigoi, Courtney E. Ostromecki, Madelyn A. Fischer, Mitchell Shorgan. (2021). Published first in the Undergraduate Research in Natural and Clinical Science and Technology (URNCST) Journal. This is an open access article distributed under the terms of the Creative Commons Attribution License (https://creativecommons.org/licenses/by/4.0/), which permits unrestricted use, distribution, and reproduction in any medium, provided the original work, first published in the Undergraduate Research in Natural and Clinical Science and Technology (URNCST) Journal, is properly cited. The complete bibliographic information, a link to the original publication on http://www.urncst.com, as well as this copyright and license information must be included. 
UNDERGRADUATE RESEARCH IN NATURAL AND CLINICAL SCIENCE AND TECHNOLOGY (URNCST) JOURNAL

Read more URNCST Journal articles and submit your own today at: https://www.urncst.com



URNCST Journal

"Research in Earnest"

\section{Funded by the \\ Government \\ of Canada}

Canadà̀

Do you research in earnest? Submit your next undergraduate research article to the URNCST Journal!

| Open Access | Peer-Reviewed | Rapid Turnaround Time | International |

| Broad and Multidisciplinary | Indexed | Innovative | Social Media Promoted |

Pre-submission inquiries? Send us an email at info@ urncst.com | Facebook, Twitter and LinkedIn: @URNCST

Submit YOUR manuscript today at https://www.urncst.com! 